\title{
A comparative analysis of human capital information opaqueness in South Korea and the UK
}

\begin{abstract}
Design/methodology/approach

Using 2018 as a sample period, content analysis is used to evaluate the annual reports of the 25 largest British and 25 largest Korean firms to demonstrate the propensity of British/Korean firms to disclose human capital information as numerical and textual data.
\end{abstract}

\section{Purpose}

Human capital is considered by many to be a firm's most important asset. However, because no international human capital reporting framework exists, firms can decide to include/exclude human capital details on annual reports. Based on legitimacy theory, firms that disclose high levels of human capital information can be considered congruent with the expectations of society. However, firms can also choose to include human capital information on annual reports for symbolic purposes as an image management strategy.

\section{Findings}

We report that South Korean firms provide high levels of human capital information using narrative and numerical data, including value added human capital elements included on Integrated Reports. British firms on the other hand tend to use primarily 
positive narrative and limited numerical human capital data to present human capital information.

\section{Originality/value}

The results imply South Korean firms provide robust human capital information on annual reports as a legitimacy strategy. On the other hand, the UK's human capital reporting requirement can be considered as a form of image management. The results therefore have important policy implications for legislators, labour unions and firm stakeholders with incentives to enhance human capital information transparency.

Keywords: annual reports; human capital; legitimacy theory; UK; South Korea; accounting policy

\section{Introduction}

Human capital is considered by many to be a firm's most important asset (Audea et al., 2005; Chen et al., 2008; Curado et al., 2011; Guthrie et al., 2012; Guthrie and Petty, 2000; Johanson, 2001; Mouritsen et al., 2001; Sung et al., 2018; Sveiby, 1997). Resourcebased theory implies that firms can be considered homogeneous. However, the value adding abilities of employees are a heterogeneous driver which provides firms with a comparative advantage relative to peers (Barney et al., 2001, Branco and Rodrigues, 2009; Edvinsson and Sullivan, 1996; Hitt et al., 2016). Whilst it is widely recognized that human capital can enhance firm performance, the value adding ability of employees is opaque because human capital information is not reported on a consistent, comparable or structured basis internationally. Based on the current reporting paradigm, firms can choose to report human capital information to varying degrees using one of three 
reports. The first report that provides firms with a platform to report human capital information is the annual report. The annual report is considered the most important document for investors (Dumay, 2016), with arguments that all other reports are considered to be of secondary status (Caddy, 2000; Gowthorpe, 2009; Power 2001). However, there are no rules that mandate human capital should be recorded on annual reports. The second report with the potential to provide human capital information is the Corporate Social Responsibility (CSR) report. CSR reporting is valued by market participants as an ethical and environmental benchmark. However, CSR reports have been criticised as having limited human capital disclosures (Beattie and Thomson, 2007; Brennan, 2001; Guthrie and Petty, 2000) and credibility (Cho et al., 2012; Hopwood, 2009; Merkl-Davies and Brennan, 2007; Moneva et al., 2006). Third, the Integrated Report (IR) is recognized as a document with the potential to overcome the opaqueness of human capital reporting because IR is a single document that links intellectual capital values such as human capital and firm performance (Abeysekera, 2013; Cuozzo et al., 2017; Dumay, 2016; Melloni, 2015; Veltri and Silvestri, 2015; Vitolla et al., 2019). However, whilst IR can enhance human capital reporting quality, few firms report human capital details using the IR framework.

There is increasing impetus in the accounting profession and accounting literature to find solutions to the human capital problem (Bassi et al., 2015; Fincham and Roslender, 2003; McCracken et al., 2018; Roslender et al., 2012). Over the past 60 years, arguments about how best to resolve the human capital problem have varied. The first field of research considers the association between human capital and firm value. There have been arguments that human capital should be directly recorded on financial statements as asset or equity values (Flamholtz, 1974; Hermanson, 1964; Hekimian and Jones 1967; Wall et al., 2003). However, others argue that human capital should not be 
recorded on a firm's balance sheet because humans cannot be owned by firms (Flamholtz, 1975). Thus, more recent studies measure the value added by investment in human capital including training, amongst others (Ballot et al., 2006; Sun et al., 2020). The second field of research is based on legitimacy theory, a critical perspective underpinned by the logic that a firm's values are congruent with society (Deegan, 2009; Lindblom, 1993). Firms that provide robust human capital information can be considered as meeting the expectations of society (Abeysekera and Guthrie, 2005; Guthrie et al., 2004, 2006). However, in the absence of structured human capital reporting rules, powerful groups may report human capital as an image management strategy, not as a genuine legitimacy strategy (Guthrie and Parker; 1989; Tinker, 1980; Tinker and Neimark, 1987). Thus, the second field of research identifies potential limitations in annual reporting to offer solutions. This paper is designed to be a critical piece to address the limitations of British annual reporting compared to an emerging economy, South Korea. More specifically, the study will identify whether human capital reporting quality can be empirically captured as being relatively transparent/opaque in both countries.

This study has several motivations. First, increasingly, there are arguments that annual reports are limited (Power, 2001; Siegel, 2006). Based on the current annual reporting paradigm, the influence of skilled, high quality human capital may be considered a black box in relation to firm performance (Lev and Zambon, 2003). Others argue that without more precise metrics or disclosures, the credibility of corporate accounting reports are undermined (Adams, 2015; Eckstein, 2004; Khan and Khan, 2010). Whilst various reports exist to report human capital information, the report most commonly used by market participants including shareholders is the annual report. Various scholars suggest that additional notes and disclosures have the potential 
to improve the transparency and information quality of annual reports (Caddy, 2000; Gowthorpe, 2009; Power, 2001). This study aims to capture the levels of available human capital information to provide examples of best practice based on a comparative analysis basis. Therefore, this study will capture the usefulness of human capital information on the annual reports in South Korea and the UK to offer suggestions to policymakers and legislators.

Second, La Ferle et al. (2013) surmise that the literature can be extended by international comparative analysis studies that determine whether/or not the attitudes of firms and individuals are equal in specific geographical locations. Ferraris et al. (2019) show that several moderating factors influence the attitudes of groups in specific countries, implying that there may be a divergence in the perceived importance of human capital reporting quality internationally. Recent studies report that human capital reporting is generally higher in developed countries compared to developing countries. However, there is evidence that the UK has lower levels of human capital compared to other developed countries (Bassi et al., 2015; Fincham and Roslender, 2003; Li et al., 2008; Vandemaele et al., 2005). Therefore, this study is motivated to report whether a developing country such as South Korea (WTO, 2021) that has been considered equivalent to a Sub-Saharan country in 1953, has the potential to surpass the human capital reporting quality of a developed economy.

Third, the study is designed to show whether South Korea and the UK have different attitudes towards human capital reporting. South Korea has put human capital development at the heart of its national productivity strategy following the Korean War (Hundt, 2015; Kim et al., 2010; Kim and Rowley, 2006; Lee, 2005; Lee, 2015; Lim and Mali, 2020). On the other hand, following the Second World War, many argue that in the 
UK the rights of employees have decreased with shareholder profit being considered of a higher priority (Koumenta and Williams, 2019; Metcalf, 1989; Nolan, 1989, 2011, 2012). Therefore, the study questions whether these different human capital strategies are represented on the annual reports of both countries. Furthermore, in the UK, there is an increasing focus on diversity as a sustainability issue (Agyemang-Mintah and Schadewitz, 2019; Martin et al., 2008). In South Korea, due to the rapidly declining birth rate, paternity/maternity issues can be considered an important sustainability issue. This study is therefore motivated to report whether based on country specific sustainability issues, if firms have a higher/lower propensity to report specific human capital values.

Fourth, management have a strong incentive to legitimize business activities. The literature suggests that numerical information is considered of higher quality compared to narrative on annual reports because it confirms a firm's actions (Abhayawansa, 2011; Guthrie and Petty; 2000; Melloni, 2015). However, firms can choose to use narrative, numerical data or both to report human capital information. This study considers narrative information to be symbolic relative to numerical information in tables and sentences that include both narrative and numerical data. Thus, the paper is motivated to discover the propensity of Korean/British firms to report human capital information using comparable numerical disclosures or unstructured narrative on annual reports. Fifth, likewise, this paper is motivated to report the propensity of human capital information disclosed as positive/ neutral language. Reporting the majority of human capital information as positive narrative could be considered as symbolic whilst reporting numerical data using neutral language could be considered a true legitimizing strategy. Thus, disentangling the use of how language is used in both countries can 
provide important insight to the human capital and accounting literatures, policymakers, labour unions and market participants.

Sentence structure content analysis is used to capture the occurrence of human capital disclosures on the annual reports of largest 25 British firms and 25 of the largest 27 South Korean firms where annual reports were available in English. The results of empirical tests show that i) South Korean firms have a higher propensity to report human capital data compared to British firms. ii) Based on a top 50 ranking system, 21 of the top 50 firms are Korean based on human capital occurrences, iii) The information quality of the 22-25th ranked Korean firm is low, as is the information quality of the 2225th ranked British firms. Taken together, the results show that there is a disparity between the reporting quality of the firms with the highest/lowest reporting quality, iv) Correlation analysis based on human capital occurrences and Fortune 500 listing, firm assets, market value and profit is insignificant for British firms. There is a negative correlation between asset value and human capital occurrences for South Korean firms. The results suggest that smaller firms provide higher levels of human capital information to attract employees and accommodate stakeholders relative to the most dominant firms. v) South Korean firms report higher levels of numerical data compared to British firms. vi) South Korean firms report higher levels of important human capital information identified in Integrated Reports as value adding compared to British firms. vii) There is also evidence that specific country characteristics/attitudes are present in annual reporting. British firms have a higher propensity to include diversity and benefit variables. South Korea reports paternity/maternity details at a rate of 1,700\% higher compared to the UK. The results suggest that the sustainability issues that are important in both countries can be represented on annual reports to different degrees. viii) 
Empirical tests also report that higher levels of human capital occurrences are reported as being positive in the UK, but neutral in South Korea.

For brevity, contributions are discussed in detail in the conclusion and discussion section. Highlights are listed below: i) British human capital information is primarily recorded using positive narrative. The results suggest that human capital information on British annual reports is not comparable, consistent or structured. Taken together, the results suggest that human capital reporting on British annual reports can be considered an image management strategy and not a genuine legitimizing strategy. ii) South Korea firms provide statistically significantly higher levels of human capital data compared to the UK. South Korean firms also provide human capital data using primarily numerical data and neutral language. Therefore, human capital information in South Korea is provided on a comparable, consistent and structured basis. In short, Korean market participants can compare the training expenses, contract type and gender pay gap for all of the top 25 Korean firms. This is not possible in the UK using the same sample. The results demonstrate that relative to the UK, Korea has a commitment to reporting human capital values consistent with a genuine legitimacy strategy. Thus, if South Korea (a developing economy) adopted the human capital policy of the UK (a developed economy), there is the potential that its workforce would be disadvantaged, because human capital information is required by labour unions for collective bargaining. iii) Integrated Reports are considered to be important documents for investors because they provide intellectual capital variables shown to add value to firm performance. However, these values are not required to be explicitly stated in annual reports. Korean firms provide high levels of IR information on annual reports. IR disclosures for the UK sample are limited. iv) The results also imply that specific sustainability issues in both countries are presented with differing 
propensity. v) There are ongoing debates about ways to improve human capital reporting with evermore reports being developed. A normative approach is applied to offer policy suggestions. It is suggested that legislators should mandate that human capital information be included on annual reports on a comparable basis internationally to enhance annual reporting quality.

The remainder of this paper proceeds as follows. In section 2, relevant literature is reviewed, and hypotheses are developed. In section 3, sample selection details and the study's research design are introduced. In section 4, empirical results are provided. Section 5 concludes by discussing the main findings, listing contributions and providing avenues for future research.

\section{Literature review and hypothesis development}

\section{Literature review}

No single intellectual capital definition exists (Dumay 2014; Gowthorpe, 2009; McPhail, 2009; Sveiby, 1997). Intellectual capital refers to all forms of intangible assets that contribute to a firm's value creation (Ashton, 2005; Dumay, 2016; Lev and Zambon, 2003). Intellectual capital is subdivided into three components in the extant literature,

i) internal (structural) capital, ii) external (social/relationship) capital, and iii) human capital. i) Intellectual capital includes a firm's culture, systems, databases management, philosophy and information technology (Bontis, 1998; Meritum, 2002; Mouritsen and Roslender, 2009). ii) External capital is a measure of a firm's relations with stakeholders including partners, customers, supplier and policymakers, that can be measured using customer loyalty, client satisfaction, brand value and firm reputation (Tsai and Ghoshal, 1998; Vitolla et al., 2020). Human capital refers to the knowledge, ability and skills of a firm's workforce. Human capital is recognized as being a firm's most valuable asset 
(Curado et al., 2011; Guthrie et al., 2012; Guthrie and Petty, 2000; Johanson, 2001; Mouritsen et al., 2001; Sánchez et al., 2001; Sveiby, 1997). The value added by human capital is linked to resource-based theory. Resource-based theory implies that firms are homogeneous; however, the value adding ability of employees is heterogeneous amongst firms, which leads to a comparative advantage (Barney et al., 2001, Branco and Rodrigues, 2009; Edvinsson and Sullivan, 1996; Hitt et al., 2016). Bounfour et al., (2008) report that human capital investment will have economic implications for firms. However, accounting legislation does not mandate that non-financial information such as human capital should be recorded on annual reports on a structured, consistent and comparable basis internationally. Thus, there is academic tension about developing potential strategies to enhance human capital information transparency.

Of the three reports that are recognized as providing human capital information, the annual report can be considered the most important document for investors (Dumay, 2016). Annual reports are designed to give (potential) shareholders and stakeholder information for investment decision making purposes (IFRS, C., 2018). There have been various attempts to develop a methodology to empirically measure intangible assets on annual reports (Branstorm et al., 2009a, 2009b; Marr and Chatzkel, 2004). However, the current policies to report intellectual capital are IFRS 3, 'Business Combinations' and IAS 38 'Intangible Assets'. Both allow intellectual capital to be recorded as intangible goodwill. El Haj et al. (2020) report that annual reports are divided into three sections. i) At the start of a document and at the discretion of management, narrative including the CEO's message is reported on an unstructured basis. ii) The financial statements follow. Financial statements must adhere to accepted accounting rules, but there are no rules that require human capital to be recorded on a consistent basis. iii) Footnotes provide management with an opportunity to disclose any 
additional information relating to financial statement value. In the footnotes, information is recorded on an unstructured basis. Overall, the current annual reporting framework allows management to disclose human capital information on an ad hoc unstructured basis. Abeysekera and Guthrie (2005) report that without the requirement for management to include intellectual capital information on annual reports on a structured basis, management are provided with an opportunity to only disclose positive information as an image management strategy. It is therefore possible for firms to 'cherry pick' human capital achievement as narrative at the start of the annual report but provide very little numerical data regarding human capital investment on financial statements or footnotes.

Because there are no requirements regarding the disclosure of human capital amongst other forms of intellectual capital on annual reports, critics of the current reporting system suggest that the accounting profession must respond to the limitations of how intangible assets are measured (Power, 2001; Siegel, 2006). Barth and Clinch (1998) argue that in a knowledge economy, the propensity of a firm to create value through intellectual capital as opposed to physical assets is increasing. Lev and Zambon (2003) report that the traditional historical cost model means that intangibles such as human assets are unknown. As a result, the true causes of firm performance can be considered opaque without considering a human capital component. Numerous studies suggest that additional notes and disclosures are demanded by market participants to improve information quality and transparency (Caddy, 2000; Gowthorpe, 2009; Power, 2001). Taken together, the literature suggests that in the absence of a clearly defined human capital component in annual reports, the association between human capital and firm performance is opaque, leading to a situation in which market participants are 
likely to demand higher levels of human capital information, based on what is currently required by law in many countries.

Critics surmise that annual reports are focused on financial performance excluding a social reporting element, which limits the potential for market participants to evaluate a firm's ethics in conjunction with financial information (Cho et al., 2010). CSR reports offer organizations a platform and a framework to report a firm's environmental, human rights and business impact, with the Global Reporting Initiative being the most commonly referenced framework in academic studies (Abeydeera, et al., 2016; De Villiers and Sharma, 2020; Khan and Gray, 2016). CSR reports can be considered an important public tool that identify a firm's ethical responsibilities including human capital (rights) practices and sustainability objectives (Wilburn and Wilburn, 2013). Increasingly, organizations are adopting CSR reports to enhance their reputation and to legitimize business activities (Leung and Gray, 2016; Mistry et al., 2014; Rao and Lilit, 2016). However, CSR reporting has been criticised in the literature for its lack of relevance and credibility (Husillos et al., 2011). Studies report human capital disclosures/information included on CSR reports are limited (Beattie and Thomson, 2007; Brennan, 2001; Guthrie and Petty, 2000). There is also evidence that CSR reporting is symbolic (Michelon et al., 2015). Critics also surmise that CSR reporting can be considered as a tool, utilized by firms to manage their corporate image (Cho et al., 2012; Hopwood, 2009; Merkl-Davies and Brennan, 2007; Moneva et al., 2006). Therefore, the literature suggests that CSR reporting can be used as a means to hold firms accountable for business ethics; however, a limitation is that the link between firm performance and social/environmental responsibility is not explicitly made in CSR/sustainability reports. 
The International Integrated Reporting Framework (IIRC) is a recently developed framework established with the ambition to overcome the limitations of annual/CSR reporting. An Integrated Report is a single document designed to provide market participants with information about organization effectiveness by illustrating the relationship between various forms of intellectual capital and firm performance, using comparable intellectual capital measurements (IIRC, 2015). The primary purpose of IR is to report how improvements in capital management can achieve improvements in performance over an extended time period (Atkins and Maroun, 2015; De Viliers and Sharma 2020; IIRC, 2013, 2015). IR provide insights about six forms of intellectual capital (natural, financial, manufactured, social, relationship and human), with all measures being defined using numerical measurements (Busco et al., 2013; Melloni, 2015). IR can therefore be considered somewhat of a breakthrough in human capital reporting because it provides market participants with valuable insights about how investment in human capital, using a standardized empirical measurement influences relative organizational effectiveness.

Increasingly, the human capital metrics included on IR are shown to add value. Vitolla et al. (2019) find that robust human capital management is associated with increasing financial performance (return on equity). Lee and Yeo (2016) show that the quality of IR is associated with increasing firm value. Zhou et al. (2017) report that firms with a close alignment to IR are associated lower cost of equity capital and a reduction in analyst forecast errors. There is also evidence that firms that adopt IR as well as traditional measures are likely to enjoy lower borrowing costs (García-Sánchez and Noguera-Gámez, 2017). Barth et al. (2017) report that firms with high IR quality are associated with higher firm value and strong cash flows. In addition to establishing a positive relationship between organizational effectiveness and firm performance, 
studies show that IR enhances reporting quality. Knauer and Serafeim (2014) demonstrate that firms that adopt IR are more likely to attract long-term investors as a result of greater transparency. Serafeim (2015) shows that companies with robust IR reporting have lower levels of transient investors, likely as a result of reduced information asymmetry (inequality). Whilst IR information can be considered important for market participants, the adoption of IR is slower than the IIRC would have liked (Dumay et al., 2017). Flower (2015) suggests that the adoption of the IIRC framework is the victim of 'regulatory capture' suggesting that IR adoption may be resisted by powerful political interests including the accounting profession amongst others.

Because human capital can be considered a firm's most valuable asset, there remains an impetus in the accounting literature and profession to determine best practice for human capital reporting (Bassi et al., 2015; Fincham and Roslender, 2003; McCracken et al., 2018; Roslender et al., 2012). Historically, there have been arguments that human capital should be recorded as an asset on the balance sheet (Flamholtz, 1974; Hermanson, 1964; Hekimian and Jones 1967). Others argue that human capital can be considered a form of equity (Wall et al., 2003). However, Flamholtz (1975) surmises that reporting humans on financial statements is flawed because it treats employees as objects to be used by firms when employees cannot be owned outright by an organization.

Because no consensus exists about the best method to record human capital information on annual reports, non-financial reporting (NFR) has the potential to enhance financial reporting quality and transparency (Baboukardos and Rimmel, 2016). NFR refers to the formal communication of information that can be considered important to stakeholders, but not emphasised within mainstream accounting 
frameworks (Jackson et al., 2019; Stolowy and Paugam, 2018). Stolowy and Paugam (2018) report two reasons why firms have a growing propensity to disclose NFR information. First, NFR disclosures enable market participants to associate intellectual capital and firm value. If two firms were considered equal based on financial fundamentals, in a situation where firm X disclosed a higher level of NFR human capital information (such as employee turnover, satisfaction and well-being) compared to firm $\mathrm{Y}$ on a structured year-on-year basis, investors are likely to have greater confidence regarding the organizational effectiveness of firm X. Second, transparent NFR disclosures can be considered a signal of business ethics. Deloitte (2015) surmises that to maintain the delicate balance between human and business needs, information about human capital can provide insights to preserve business ecosystems. Jackson et al. (2019) surmise that NFR information promotes socially responsible values. Taken together, in the absence of structured human capital information, stakeholders' ability to make informed decisions about firm ethics and firm performance is limited. Increasingly, there is a growing impetus to acknowledge that NFR information has the potential to enhance corporate governance legislation worldwide (KPMG, 2016). Thus, studies that recognize variations in human capital reporting internationally can provide policymakers with insights to enhance governance codes and extend the accounting framework.

Duff (2018) analyses the voluntary disclosures of British accounting firms. The study shows that human capital information is not reported on a structured basis on annual reports. Moreover, British accounting firms are shown to report human capital values including employee information, education, training, satisfaction amongst others as a legitimacy strategy to communicate status and reputation. Abeysekera and Guthrie (2005) conduct content analysis to investigate the robustness of the human capital 
reporting framework in Sri Lanaka. The study reports that Sri Lankan firms are increasingly providing a higher level of human capital on annual reports. The increasing propensity to issue robust human capital information is underpinned by legitimacy theory. Legitimacy theory implies that a firm is congruent with expectations of society (Lindblom, 1993; Deegan, 2009). Guthrie et al. (2006) report that management have an incentive to report human capital information because it legitimizes business activities over and above mandatory requirements, in order to meet the expectations of stakeholders. Guthrie et al. (2004) posit that management can control the perception of market participants if human capital information in effectively communicated.

However, critics argue that human capital reporting can be used by management as an image management strategy (Tinker, 1980; Tinker and Neimark, 1987). Guthrie and Parker (1989) imply that accounting reports are designed to sustain and legitimise the private economic and political interests of firms, as opposed to providing accurate information to stakeholders. Thus, in the absence of an accepted human capital framework, human capital information can be recorded by management on an unstructured basis. Abeysekera and Guthrie (2004) conduct content analysis using a broad range of human capital values including health and safety, innovation, diversity, career development and employee competency (to proxy for human capital) to determine whether the human capital information demanded by stakeholders is supplied by Sri Lankan/Australian firms. They find that the propensity of Australian firms to report human capital data is higher compared to Sri Lankan firms, suggesting that both countries attach a different value on human capital data. Vergauwen and VanAlem (2005) demonstrate that there is variation in human capital information based on the country's legal infrastructure. The study surmises French, German and Dutch firms can be ranked by descending disclosure quality from the former to the latter. The 
study implies that there is a requirement for a convergence in accounting standards and practices to enhance corporate governance. Taken together the literature demonstrates a situation has emerged in which the quality of human capital information differs by country, leading to a situation where management is free to disclose a different level and quality of human capital information. Thus, a situation has emerged where international comparative analysis of human capital reporting quality/quantity can offer insights about the legitimacy of national accounting frameworks.

In this study, we are interested in whether human capital reporting quality is different in the UK compared to South Korea. The UK is a major international financial hub with a strong reputation for policymaking and legislation. However, the literature reports that human capital reporting is not robust in the UK. Vandemaele, et al. (2005) show that human capital disclosure quality of Swedish firms is higher compared to British firms. There is also evidence that Scandinavian counties have higher levels of human capital information on annual reports compared to other European countries including the UK (Fincham and Roslender, 2003; Roslender and Stevenson, 2009). Furthermore, numerous other studies show that human capital reporting is relatively weak in the UK (Bassi et al., 2015; Li et al., 2008; Steen et al., 2011; Striukova et al., 2008). Critics of the UK system report that following the Second World War, the reason why British organizations have lower human capital reporting quality is because the UK has moved away from a philosophy of being employee focused to be controlled by private equity holders (Metcalf, 1989; Nolan, 2011, 2012). In the UK, the current paradigm has led to a situation in which zero hour and non-standardized contracts are becoming the norm, replacing full time employment (Koumenta and Williams, 2019). The reduction of staff working conditions and a lack of human capital information can be considered linked based on labour unions requiring human capital information for 
collective bargaining (Americ, 1985; Craft, 1981; Maunders and Foley, 1984; Mautz, 1990), but this information may be absent. Because firms are not required to report human capital information on a structured, consistent and comparable basis on annual reports internationally, a situation may have emerged in which the potential deterioration of British employees' working condition cannot be quantified. Managers have the potential to maintain the status quo by managing their public image using narrative and not disclosing numerical human capital data, which provides firms an opportunity to place shareholder wealth above employees.

The reason why South Korea can be considered as having a different outlook on human capital reporting to the UK is because: firstly, following the Korean War, the economy could be considered equivalent to a modern day Sub-Saharan country. Due to limited national resources, South Korea's post-war productivity policy has been based on developing human capital (Hundt, 2015; Kim, 2010; Lee, 2005; Kim and Rowley, 2006; Lee, 2015; Lim and Mali, 2020). Therefore, robust human capital reporting can be considered important to South Korean legislators. Second, weak legislation was considered to be a major contributing factor in the Asian Financial Crisis in 1997 (LaPorta et al., 1997). During the financial crisis period, Newson and Deegan (2002) surmise that South Korea's corporate reporting quality was considered lower compared to Singapore and Australia. A study by Subbarao and Zegna (1997) also report that South Korean firms are also more likely to exclude important human capital information compared to the UK and USA. A more recent report by FTSE stock exchange report that South Korea meets the criteria of a developed country, however its legal frameworks can be considered weaker than developed nations (Woods, 2013). The economy is now ranked $11^{\text {th }}$ based on GDP. More recently, South Korea has adopted various financial reporting quality strategies to improve its international image (Choi et 
al., 2017; Lim and Mali, 2020; Mali and Lim, 2018, 2019, 2020, 2021). Therefore, to legitimize the business activities of Korean firms, South Korean firms have an incentive to report higher levels of human capital information compared to other countries. However, whether or not South Korea and the UK report a different level of human capital information/quality is a question left unanswered.

\section{Hypothesis development}

Listing sufficient human capital information as both narrative and numerical data can be considered congruent with the expectations of society and in a firm's best interest because it legitimizes business activities (Deegan, 2009; Guthrie et al., 2004; Lindblom, 1993; Schuman, 1995). However, because there are no explicit human capital reporting rules internationally, it is at the discretion of managers the level of human capital information included on annual reports. As a result, management can choose to report human capital information using predominantly positive narrative as an 'image management' tool. On the other hand, management can choose to report human capital information using numerical data and neutral narrative as a genuine legitimacy strategy. As a further legitimizing strategy, firms can choose to report IR values. This study will demonstrate which strategy is adopted by Korean and British firm samples.

It is hypothesized that British firms will include higher level of human capital information as narrative compared to numerical data. It is also hypothesized that South Korean firms are more likely to provide i) more human capital information compared to British firms, ii) a higher percentage of human capital information using numerical data (or both narrative and numerical data in a single sentence), and iii) provide higher levels of IR human capital information data. The above hypotheses imply that the 
human capital reporting quality of South Korean firms is higher than British firms. The hypotheses also imply that British firms are also likely to report human capital information as an image management tool; by comparison South Korean firms' human capital reporting can be considered as a genuine legitimacy strategy. South Korean human capital information is considered to be higher than British firms based on the following. First, South Korean legislators have incentives to mandate that all firms have transparent reporting systems. South Korea's legal infrastructure has been considered relatively weaker compared to developed nations (LaPorta et al., 1997; Woods, 2013). To repair its image, the South Korean government and financial institutions have taken numerous steps to improve financial reporting quality (Choi et al., 2017; Mali and Lim, $2018,2019,2020,2021)$. Internationally, the opaqueness of human capital data is referenced as a black box in relation to firm performance (Lev and Zambon, 2003). Thus, for South Korea, robust human capital reporting can be considered a legitimizing strategy to enhance investor confidence. On the other hand, the UK is one of the largest financial markets. Therefore, because it is an established international financial market, policymakers and legislators have no incentives to challenge the status quo by mandating that firms include additional human capital data on annual reports. Second, South Korea and the UK have different philosophical outlooks on human capital. The UK is recognized as having lower levels of human capital information compared to many other developed economies (Bassi et al., 2015; Fincham and Roslender, 2003; Li et al., 2008; Roslender and Stevenson, 2009; Steen et al., 2011; Striukova et al., 2008; Vandemaele, et al., 2005). A potential reason why human capital information is not robust in the UK is because following the Second World War, shareholder profit has superseded employees' wellbeing as an organizational strategy (Koumenta and Williams, 2019; Metcalf, 1989; Nolan, 1989, 2012). On the other hand, 
following the Korean War, the Korean government placed human capital development at the heart of its international productivity strategy (Hundt, 2015; Kim, 2010; Kim and Lee, 2015; Lee, 2005; Rowley, 2006). Third, as suggested by Hofstede (2001), language has an important influence on firm behaviour. There is evidence that due to a lack of English language awareness, Korean market participants can misunderstand narrative (Cho and Yoon, 2013; Jung, 2012). Therefore, Korean firms may report human capital information using unambiguous language and numerical data to avoid any potential misunderstandings or conflicts. Based on the above, the following hypotheses are developed:

H 1.1 South Korean firms will include higher levels of human capital information (IR, numerical and narrative).

H 1.2 British firms will include higher levels of human capital information using narrative (as opposed to numerical data) compared to South Korean firms.

\section{Methodology}

\section{Research Design}

Details of the research strategy are included in Appendix 1. Content analysis is employed to analyse the differing levels of human capital information on Korean and British annual reports. Content analysis is a form of textual analysis that is extensively used in the accounting literature to code qualitative and quantitative data into predefined categories to identify the context, conventions and the patterns of texts (Abeysekera and Guthrie, 2005; Abeysekera and Guthrie, 2004; April et al., 2003; Beattie et al., 2004,2005; Beattie and Thomson, 2007; Bontis, 2003; Bozzolan et al., 2003, 2006; Brennan, 2001; De Silva et al. , 2014; Duff, 2018; Guthrie et al., 2004, 2007; 
Guthrie and Petty, 2000; Striukova et al., 2008). The primary objective of the study is to discover whether British firms and Korean firms provide higher or lower levels of human capital information using narrative, numerical data or both. Therefore, the initial research design step has been to determine which human capital information is important to the extant literature and readership. Human capital occurrences are categorised based on previous studies (Abeysekera and Guthrie, 2005; Duff, 2018; Guthrie and Petty, 2000; Huang et al., 2013; McCracken , 2018; Striukova et al., 2008). In Table 1, the human capital variables identified in this study are listed. A secondary objective of this study is to determine whether British or South Korean firms have an equal propensity to list the human capital variables included on Integrated Report. Human capital values with a corresponding (IR) reference are those important numerical human capital variables that are recognized as being value adding in IR.

<Insert Table 1 roughly here>

The next step is to capture human capital variables empirically. To measure an occurrence (non-occurrence) of human capital information as narrative or numerical data, the sentence count method is chosen as the context unit. The sentence count methodology has been chosen instead of page, paragraph or word count because a whole sentence is considered to be recognizable for meaning and categorization purposes (Carney, 1972; Gray, 1995). The sentence count also has advantages because information included in tables and charts can easily be converted into equivalent sentence structures (Abeysekera and Guthrie, 2004). All titles and headings are excluded from the analysis. To discover whether a sentence unit includes human capital information, the following steps were taken. First, the Wordsmith program is used to evaluate all the linguistic content of the two largest South Korean and British firms. Then after carefully analysing words associated with human capital, a Wordlists was 
developedi. Second, Beattie and Thomson (2007) explain that content analysis requires a clear description of how a category occurs to make qualifications to categorize information resulting from its existence/non-existence to avoid 'boundary problems'. To avoid boundary problems, a group of words in a sentence is treated as a text unit, as suggested by (Beattie et al., 2004). Therefore, if different elements are included in the sentence, they are treated as a single occurrence. For example, if staff satisfaction and training were referenced in a single sentence, both elements would be considered as an occurrence and coded as two separate occurrences. However, if training was referred twice in a single sentence, it would be treated as a single occurrence.

Third, after completing a list of all sentences that include a human capital occurrence, the next step is to record whether information is recorded as narrative or numerical data, or both. Studies emphasize the importance of narrative information in intellectual capital reporting (Bozzolan et al., 2006; Husin, et al., 2012; Striukova et al., 2008). However, Guthrie and Petty (2000) argue that intellectual capital reporting using narrative is of lower quality compared to numerical information. Duff (2018) reports British accounting firms disclose intellectual capital regularly using numerical data, implying that narrative information is of lower quality. Critics of a narrative reporting explain that empirical information is more verifiable compared to narrative exclusively (Abhayawansa, 2011; Melloni, 2015). In this study, numerical data is also considered to be of higher quality compared to narrative. To capture whether human capital is recorded as narrative (NAR) or numerical data in tables (NUM), each sentence occurrence is identified as a value of $0 / 1$ on a cumulative basis. If both NAR and NUM are included in a single sentence, it is coded as (BOTH). Total occurrences are referenced as TOTAL. 
Next, pilot tests were conducted by both reviewers with a single annual report to ensure that the methodology was well-designed. Based on previous studies, because the population of the largest firms (in the UK and South Korea) would be equivalent (Abeysekera and Guthrie, 2005; Gray et al., 1995; Kirkman and Hope, 1992; Mitchell et al., 1995), it was decided that t-test mean difference analysis would be an appropriate data analysis method. T-test analysis is used because it allows a direct comparison based on established statistical significance measures. As a good practice strategy and to reduce subjectivity, two individuals conducted content analysis and coded the results independently. To reduce researcher bias, the reviewers (authors) are from South Korean and the UK respectively. Because the reviewers are from the countries which are the basis of the content analysis, it is likely that any unconscious researcher bias would be mitigated as a result of both reviewers having equal bias towards their country of birth. As an additional good practice strategy, a single reviewer conducted content analysis for all 50 annual reports. Next, the second reviewer independently reviewed 24 annual reports, 12 from the UK and 12 South Korea. Then, the two reviewers compared results in a series of meetings. It was discovered that the analysis of both reviewers was largely equivalent. Thus, taken together, the agreed final dataset coding can be considered free from researcher bias.

\section{Sample selection}

To capture how human capital information is recorded on annual reports, the annual reports of the largest 25 British firms based on the 'Fortune 500' ranking are downloaded from company websites for the 2017-2018 financial period. Due to data unavailability, the (English) annual reports for 25/27 largest Korean firms have been downloaded in the 2017-2018 financial period and utilized for this study because the 
annual report for the $22^{\text {nd }}$ and $26^{\text {th }}$ largest Korean firm were unavailable in English. In Table 2, the financial details of selected firms are shown. All values are listed in millions of dollars. Overall, British firms have slightly higher levels of revenue and profit compared to Korean firms. However, British firms are larger based on assets and market value.

<Insert Table 2 roughly here $>$

\section{Empirical results}

In Table 3, the levels of human capital occurrences are recorded for the top 25 Korean and British firms (where data is available). Table 3 is dived into two main columns. The left column provides details about human capital occurrences as raw data. On the right hand side, a weighting of $\left({ }^{*}\right) 2$ is added to NUM and a weighting of $\left({ }^{*}\right) 3$ is added to BOTH to account for previous studies that suggest numerical data is more informative compared to narrative (Abhayawansa, 2011; Guthrie and Petty, 2000; Melloni, 2015). Using the raw data occurrence values, 21 of the top 25 Korean firms have more human capital information (occurrences) compared to the highest ranking British firm. The firms ranked $22^{\text {nd }}$ to $39^{\text {th }}$ are British firms. The results demonstrate that whilst Korean firms provide higher levels of human capital information compared to British firms, there are a handful of Korean firms (4) that also offer very little human capital information. There is strong support for hypothesis 1.1 based on evidence that Korean firms provide higher levels of human capital information compared to British firms. However, it must also be recognized that some South Korean and British firms offer very little human capital information. The next column of interest is 'percentage' (left side) that represents the number of NUM and BOTH occurrences divided by TOTAL 
occurrences. The results show that all but 1 of the top 21 Korean firms provide human capital information using numerical data at a rate of higher than $40 \%$. On the other hand, most British firms provide very little NUM or BOTH human capital information $(<40 \%)$. The results suggest that British firms report human capital data mainly using narrative, as conjectured in hypothesis 1.2.

\section{<Insert Table 3 roughly here>}

The next columns of interest are the relative ranking(s). On the left side (raw data), ranking is estimated by dividing a firm's human capital occurrence value with the value of the highest occurrence (374). On the right side, the value is estimated by dividing the highest occurrence (699) with all other firm's relative occurrences based on the weighting structure. A comparison of relative human capital occurrences shows that when a numerical data weighting is added to the raw data, the relative ranking of the British (Korean) firms becomes lower (higher) compared to the Korean (British) firms. The results provide evidence in support of hypothesis 1.2 , by demonstrating that Korean firms are likely to have a higher propensity to issue human capital information using NUM or BOTH, compared to British firms that are more likely to provide information as NAR.

Table 4 is an extension of Table 3 and provides the results of empirical $(t)$ tests comparing the human capital occurrences of British and Korean firms as NAR, NAR and BOTH or as a TOTAL. The first two rows show the propensity of Korean firms to report human capital information using numerical data. The results show that British firms (29.61\%) are much less likely to provide human capital information as NUM or BOTH compared to Korean firms (49.30\%). This evidence is again consistent with hypothesis 1.2. Next, $t$ tests are conducted to compare the reported levels of i) NAR ii) NUM and 
BOTH combined and iii) TOTAL (NAR, NUM and BOTH). T test are calculated as Korean data minus British data. Therefore, a positive (negative) value suggests that the Korean (British) firm sample has higher human capital occurrences compared to the British (Korean) firm sample. The results show that Korean firms have a higher propensity to report human capital as NAR (3.71***), NUM and BOTH combined $\left(6.54^{* * *}\right)$ and for TOTAL occurrences $\left(6.50^{* * *}\right)$. The results allow us to accepted hypotheses 1.1 and 1.2.

\section{$<$ Insert Table 4 roughly here>}

The top 25 firms from both Korea and the UK are included in this analysis on the basis of the Fortune 500 ranking. Therefore, a question emerges, whether firms at higher/lower rankings have higher/lower human capital occurrences? To answer this question, Pearson correlations are conducted with Fortune ranking and a) NAR, b) NUM and BOTH, and c) TOTAL occurrences. This process is then repeated for other firm specific determinants including i) revenue, ii) assets, iii) firm value and iv) profit (see Table 2). In Table 5, there is a positive association between a firm's Fortune ranking and revenue, assets, firm value and profit, as can be expected. There is also a correlation between TOTAL occurrences and NAR, NUM and BOTH, as can also be expected. The associations of interest are firm performance rankings and human capital disclosure occurrences. The results show that for British firms, there is no statistically significant association between human capital occurrences and Forbes rankings, revenue, assets, market value and profit. The Korean data suggests that there is a negative association between assets and TOTAL occurrences $\left(-0.67^{* * *}\right)$ and NAR $\left(-0.51^{* * *}\right)$, NUM $\left(-0.71^{* * *}\right)$ and BOTH $\left(-0.46^{* * *}\right)$. The results can be interpreted as firms with lower levels of assets having an incentive to legitimize business activities or attracting staff through robust human capital reporting relative to the largest more established firms. 
Table 4 shows that based on the entire sample, Korean firms provide higher levels of human capital information using NUM and BOTH, NAR and TOTAL. In Table 6, each occurrence is sub-divided into specific human capital variables (see Table 1). Then, $60 t$ tests are conducted to compare the occurrence level of each variable based on NUM and BOTH, NAR, and TOTAL. If the sample value is lower than 50, the results of tests are excluded. Values identified with (IR) are highlighted as those important human capital values reported on Integrated Reports. Consistent with Table 4, positive values can be considered as higher levels of human capital occurrences by Korean firms compared to British firms. The TOTAL t test results show that apart from benefit ($\left.6.10^{* * *}\right)$ and diversity/equality $\left(-1.91^{*}\right)$, South Korean firms have higher TOTAL human capital occurrences for 16 out of 20 variables. Again the results are consistent with hypothesis 1.1.

In the NUM and BOTH columns that measure the propensity of firms to issue numerical data, for all but one of the important (IR) numerical values, Korean firms have a higher propensity to issue IR information compared to British firms. Moreover, excluding benefit and diversity, South Korean firms provide higher levels of numerical data for the human capital variables. The results demonstrate that Korean firms have a higher propensity to issue numerical human capital data compared to British firms, consistent with hypothesis 1.2. South Korean firms also provide higher levels of NAR human capital details for 10 out of the 20 variables (at a significance level of 0.01 ) compared to British firms. But British firms provide higher levels of NAR information for diversity/equality $\left(-5.01^{* * *}\right)$ and benefits $\left(-4.31^{* * *}\right)$. The results suggest that there are some human capital values that are important to British firms, thus disclosed more 
often compared to Korean firms. This evidence combined with paternity/maternity TOTAL occurrences in South Korea (a country with a very low birth rate) being significantly higher than in the UK $(1,700 \%$ higher $)$ implies that human capital occurrences can be influenced by the sustainability ideology of a specific country.

\section{$<$ Insert Table 6 roughly here $>$}

Because there is evidence human capital information disclosures may be linked to the sustainability reporting ideologies of different countries, whether South Korean and British firms have a higher propensity to report human capital information occurrences as positive or neutral language is analysed. All negative occurrences (6) are excluded. Neutral and positive coding underwent an identical procedure with NAR, NUM and BOTH. To determine whether an occurrence is positive/neutral, the Wordsmith program concordance feature was used to determine the sentence tone for each occurrence. Sentences were determined to be positive/neutral/(negative) using adjectives and adverbs. Again, each occurrence was reviewed to ensure that the results were consistent with the program's output. Firms with higher levels of positive occurrences can be interpreted as potentially attempting to engage in an image management. Firms with more neutral language can be considered as providing human capital information as a genuine business legitimizing strategy. In Table 7, human capital occurrences are compared using $t$ tests. For all but the benefit variable, UK firms use positive language when referring to human capital. The final column divides positive occurrences by total occurrences.

The results show that overall, British firms are more likely to use positive occurrences (59\%) compared to Korean firms (25.55\%). In Panel B, t tests are conducted to compare positive occurrences and neutral occurrences. Even though the 
TOTAL occurrences of Korean firms are higher, the difference between positive occurrences is statistically insignificant $(-0.67)$. However, Korean firms are far more likely to provide human capital disclosures using neutral language (3.84***). Taken together with previous findings, relative to British firms, the results suggest that South Korean firms report human capital information as a genuine legitimacy strategy.

$$
<\text { Insert Table } 7 \text { roughly here> }
$$

\section{Conclusion and discussion}

The results of content analysis demonstrate that Korean firms have higher levels of human capital information reported on annual reports compared to British firms. Moreover, Korean firms provide (neutral) numerical human capital information including IR values on a structured, consistent and comparable basis. On the other hand, British firms provide human capital using positive narrative with limited numerical data. From a legitimacy theory perspective, the results suggest that South Korean human capital reporting is a genuine legitimizing strategy, consistent with society's expectations that firms report higher levels of human capital information than is currently required in the accounting framework (Guthrie et al, 2004; 2006). The human capital information reported on British annual reports can be considered of lower quality. Therefore, human capital information reporting on British annual reports can by comparison be considered an image management strategy, not a genuine attempt to legitimize business activities.

The results of this study have important implications for market participants, policymakers and the general public for several reasons. First, it is established that labour unions require human capital information for negotiating collective contracts (Americ, 1985; Craft, 1981; Maunders and Foley, 1984; Mautz, 1990). However, the UK 
is recognized having weaker human capital annual reporting compared to other developed nations (Bassi et al., 2015; Fincham and Roslender, 2003; Li et al., 2008; Roslender and Stevenson, 2009; Steen et al., 2011; Striukova et al., 2008; Vandemaele, et al., 2005). The British economy is also criticized for prioritizing shareholder wealth over employee welfare (Metcalf, 1989; Nolan, 1989, 2011, 2012). Therefore, the current paradigm that allows human capital information to be provided as unstructured narrative may be a contributing factor why zero-hour contracts are becoming the norm in the UK (Koumenta and Williams, 2019). If human capital information would be recorded as structured numerical data, reductions in employee conditions would be more clearly identified. Future studies may consider collecting interview and questionnaire data to crystalize why human capital information is (not) reported in the South Korea (UK). There are numerous potential reasons why different countries have high/low human capital reporting quality including; maintaining the status quo; lack of expertise or skills, and no benchmark frameworks to follow. Identifying the existence of variations and why they exist has the potential to provide insights to why international accounting frameworks do not report human capital reporting as a more prominent feature.

Second, South Korea was one of the poorest countries on earth following the Korean War. Due to a lack of natural resources, South Korea's productivity strategy following the Korean War was based on developing human capital (Hundt, 2015; Kim, 2010; Kim and Rowley, 2006; Lee, 2005; Lee, 2015; Lim and Mali, 2020). Based on its productivity strategy amongst other factors, South Korea can be considered as having a higher incentive to report human capital information on a consistent, structured and comparable basis compared to the UK. In South Korea, numerical human capital information (such as continuous employment/tenure and average male/female salary) 
is regularly reported on annual reports. Thus, current (future) employees, the government, the general public and shareholders amongst other stakeholders can evaluate firms based on human capital investment. The results imply that robust human capital reporting can be a transparency comparative advantage for Korean firms based on the increasing importance of ethical investment.

Third, South Korea provides paternity/maternity information at a rate of $1700 \%$ higher compared to British firms. The UK on the other hand only provides higher levels of human capital information for diversity/equality and staff benefits characteristics. The results imply that market conditions, economic strategies and the rhetoric associated with specific sustainability issues has led to a situation where both countries focus on specific employee level characteristics. However, South Korea has higher levels of information quality for virtually all human capital categories. These finding are linked with resource-based theory. Resource-based theory implies that firms are homogeneous. However, it is the heterogeneous characteristics of employees that provide firms with a comparative advantage. This study shows that in South Korea, the effect of employee characteristics' (input) in developing a comparative advantage (output) can be estimated using structured data. On the other hand, because of weak human capital reporting quality in the UK, this relationship is opaque to information users due to data unavailability. We would encourage studies where human capital is widely available to associate human capital and firm performance or risk. Such studies can extend the literature by demonstrating how human capital potential can enhance organizational effectiveness.

Fourth, there are ongoing debates about the advantages/limitations of reporting human capital information on i) annual reports, ii) CSR reports and iii) IR. IRs are 
increasingly being considered important documents because they report how human capital add value and influence organizational performance (Barth et al., 2017; GarcíaSánchez and Noguera-Gámez, 2017; Knauer and Serafeim, 2014; Lee and Yeo, 2016; Serafeim, 2015; Vitolla et al., 2019; Zhou et al., 2017). However, the adoption of IR is reported as being slower than expected, potentially as a result of 'regulatory capture ' (De Villers and Sharma, 2020; Flower, 2015). Therefore, a situation has emerged where some important human capital information determinates are recognized in IR but excluded from annual reports. The empirical results of this study demonstrate Korean annual reports include IR human capital information at a statically significantly higher level than the UK. Numerous studies show that shareholders demand higher levels of human capital information on annual reports (Eccles et al., 2001; Upton, 2001). This assertion is consistent with the view that including additional human capital information on annual reports is a solution to the human capital and intellectual capital reporting problem (Caddy, 2000; Gowthorpe, 2009; Power 2001). Based on evidence that IR information is included on Korean annual reports, we believe that legislators may consider mandating that the IR human capital information shown to be included on Korean annual reports are adopted internationally as a reporting quality policy enhancement.

Fifth, the majority of human capital and intellectual capital studies comparing developed and developing nations report that the human capital reporting systems of developed countries are more robust compared to developing countries (Abeysekera and Guthrie (2005; April et al., 2003; Goh and Lin, 2004; Singh and Kansal, 2011). This study shows that a developing country (South Korea) based on WTO assessment has a far more robust human capital reporting system than a developed country (UK). Dumay (2016) surmises that maintaining the current reporting system in Anglo-American 
economies is in the self-interest of equity holders and the accountants; suggesting that the political interests of powerful groups can influence policy decisions. If South Korea adopted the annual reporting system of a developed country like the UK, employees may be in a weaker position because human capital information can be considered a direct incubator of working conditions (Abeysekera and Guthrie, 2004; Dumay and Garanina, 2013; Roslender and Stevenson, 2009). This paper demonstrates that based on the top 25 British and Korean firms, the top 21 firms ranked using human capital occurrences are Korean firms. Therefore, in this instance, if a developing country based on the assessment of the World Trade Organization (WTO, 2021) adopted the human capital reporting system of a developed country, it would have a negative effect on reporting quality and transparency.

Sixth a normative statement is presented. Flamholtz (1975) surmises that because employees are not bound to an employer, human capital should not be treated as a numerical asset/capital value on financial reports. Whilst we agree that placing a \$ value on an employee is unlikely to be accepted by accounting policymakers, we posit that a more robust mechanism is required to associate the effect of a firm's workforce on organizational effectiveness. The Non-Financial Reporting literature implies that information outside of the mainstream accounting framework, such as human capital data can provide market participants with information about firm value, and business ethics (Baboukardos and Rimmel, 2016; Jackson et al., 2019; Stolowy and Paugam, 2018). From a practical perspective, evidence from this study clearly shows that Korean market participants can make inferences about the effect of; staff turnover on firm performance; or employee loyalty on default risk. Korean market participants can also base investment decisions on information associated with human capital ethics. For example, changes in full/part time and permanent/temporary contracts can be 
compared on a yearly basis. However, because workforce human capital data is not widely reported in the UK, similar firm performance and business ethics inferences cannot be made. Therefore, to generalize this study, we surmise that comparing the propensity of firms to include important human capital information on annual reports in different countries is necessary. By demonstrating that that human capital reporting quality is high/lower in specific countries, there is the potential that governments and legislators may consider passing legislation to enhance information quality, which will benefit employees, market participants and potentially society.

Finally, limitations are listed. In South Korea and the UK, public companies are required to publish annual reports in their native language. The British annual report is required by law. The 800-page Korean annual report written in the Korean language is also required by law. The English annual report is not required by law in South Korea. The English written annual report combines all information included on the Korean annual reports including financial statement information, performance disclosures, management communication and sustainability information. Thus, there is the potential for Korean firms to develop a hybrid financial/sustainability annual report as an image management tool. British firms on the other hand are expected to follow annual reporting conventions. However, the Korean annual reports are the most accessible and primary source of financial information for market participants. It is at the discretion of firms how much sustainability and human capital information is disclosed.

Furthermore, whilst the sample size is equivalent to previous studies (Abeysekera and Guthrie, 2004, 2005; Duff, 2018; Striukova et al., 2008), the sample size can be considered relatively small. We are unable to increase our sample size because not all Korean firms provide annual reports in English. It would not be possible to compare the annual reports of the top 50 Korean firms and 50 British firms because 
to the best of our knowledge, data is unavailable for 16 of the top 50 Korean firms. Thus, as the sample size of Korean firms increase, it would also increase testing bias. Likewise, we only compare the human capital occurrences of Korean and British firms over 1 year because prior to 2008, roughly half Korean firms did not publish annual reports in English. In 2018, 2 firms are missing from the dataset. Thus, we conduct content analysis using a 2018 dataset, when 25 of the top 27 Korean firms issue annual reports. It is established that firm size is an important factor when considering reporting quality because larger firms are more visible, have more assets at their disposal to manage their image, and have a higher incentive to protect their reputation through additional human capital disclosures (Abeysekera and Guthrie, 2005; Gray et al., 1995; Kirkman and Hope, 1992; Mitchell et al., 1995). Thus, a comparison of the largest Korean and British firms can be considered a robust sample selection process because the top 25 Korean and British firms are likely to have similar traits. As more Korean firms publish annual reports in English, future studies may conduct a multi-year study to analyse whether human capital information is becoming a more prominent feature in South Korean annual reporting.

\section{References}

Abeysekera, I. (2013). A template for integrated reporting. Journal of Intellectual Capital, $14(2), 227-245$.

Abeysekera, I., \& Guthrie, J. (2004). Human capital reporting in a developing nation. The British Accounting Review, 36(3), 251-268.

Abeysekera, I., \& Guthrie, J. (2005). An empirical investigation of annual reporting trends of intellectual capital in Sri Lanka. Critical Perspectives on Accounting, 16(3), 151-163. 
Abeydeera, S., Tregidga, H., \& Kearins, K. (2016). Sustainability reporting-more global than local? Meditari Accountancy Research, 24(4), 478-504.

Abhayawansa, S. (2011). A methodology for investigating intellectual capital information in analyst reports. Journal of Intellectual Capital, 12(3), 446-476.

Adams, C. A. (2015). The international integrated reporting council: a call to action. Critical Perspectives on Accounting, 27(1), 23-28.

Agyemang-Mintah, P., \& Schadewitz, H. (2019). Gender diversity and firm value: evidence from UK financial institutions. International Journal of Accounting \& Information Management, 27(1), 2-26

Amernic, J. H. (1985). The roles of accounting in collective bargaining. Accounting, Organizations and Society, 10(2), 227-253.

April, K. A., Bosma, P., \& Deglon, D. A. (2003). IC measurement and reporting: establishing a practice in SA mining. Journal of Intellectual Capital, 4(2), 165-180.

Ashton, R. H. 2005. Intellectual capital and value creation: a review. Journal of accounting literature, (24)2005, 53-134.

Atkins, J., \& Maroun, W. (2015). Integrated reporting in South Africa in 2012. Meditari Accountancy Research, 23(2), 197-221.

Audea, T., Teo, S. T., \& Crawford, J. (2005). HRM professionals and their perceptions of HRM and firm performance in the Philippines. The International Journal of Human Resource Management, 16(4), 532-552.

Baboukardos, D., \& Rimmel, G. (2016). Value relevance of accounting information under an integrated reporting approach: A research note. Journal of Accounting and Public Policy, 35(4), 437-452.

Ballot, G., Fakhfakh, F., \& Taymaz, E. (2006). Who benefits from training and R\&D, the 
firm or the workers? British journal of Industrial Relations, 44(3), 473-495.

Barney, J. B., Ketchen Jr, D. J., \& Wright, M. (2011). The future of resource-based theory: revitalization or decline? Journal of Management, 37(5), 1299-1315.

Barth, M. E., Cahan, S. F., Chen, L., \& Venter, E. R. (2017). The economic consequences associated with integrated report quality: Capital market and real effects. Accounting, Organizations and Society, 62(in press), 43-64.

Barth, M. E., \& Clinch, G. (1998). Revalued financial, tangible, and intangible assets: Associations with share prices and non-market-based value estimates. Journal of Accounting Research, 36, 199-233.

Bassi, L., Creelman, D., \& Lambert, A. (2015). Advancing the HR profession: Consistent standards in reporting sustainable human capital outcomes. People and Strategy, 38(4), 71-75.

Beattie, V., McInnes, W., \& Fearnley, S. (2004). A methodology for analysing and evaluating narratives in annual reports: A comprehensive descriptive profile and metrics for disclosure quality attributes. Accounting Forum, 28(3), 205236.

Beattie, V., \& Thomson, S. J. (2007). Lifting the lid on the use of content analysis to investigate intellectual capital disclosures. In Accounting Forum, 31(2), 129163.

Bontis, N. (1998). Intellectual capital: an exploratory study that develops measures and models. Management Decision, 36(2), 63-76.

Bounfour, A., Bismuth, A., \& Tojo, Y. (2008). Creating value from intellectual assets. Journal of $\quad$ Intellectual Capital, 9(2), 228-245.

Bozzolan, S., O'Regan, P., \& Ricceri, F. (2006). Intellectual capital disclosure (ICD). Journal of Human Resource Costing \& Accounting, 10(2), 92-113. 
Brännström, D., Catasús, B., Giuliani, M., \& Gröjer, J. E. (2009). Construction of intellectual capital the case of purchase analysis. Journal of Human Resource Costing \& Accounting, 13(1), 61-76.

Branco, M. C., \& Rodrigues, L. L. (2009). Exploring the importance of social responsibility disclosure for human resources. Journal of Human Resource Costing \& Accounting, 13 (3), 186-205.

Brennan, N. (2001). Reporting intellectual capital in annual reports: evidence from Ireland. Accounting, Auditing \& Accountability Journal, 14(4), 423-436.

Busco, C., Frigo, M. L., Riccaboni, A., \& Quattrone, P. (2013). Integrated reporting. Concepts and Cases that Redefine Corporate Accountability (Springer).

Caddy, I. (2000). Intellectual capital: recognizing both assets and liabilities. Journal of Intellectual Capital, 1(2), 129-146.

Carney, T. F. (1979). Content analysis: A technique for systematic inference from communications. University of Manitoba Press.

Chen, Y. S., Chang, B. G., \& Lee, C. C. (2008). The association between continuing professional education and financial performance of public accounting firms. The International Journal of Human Resource Management, 19(9), 17201737.

Cho, C. H., Michelon, G., \& Patten, D. M. (2012). Impression management in sustainability reports: An empirical investigation of the use of graphs. Accounting and the Public Interest, 12(1), 16-37.

Cho, C. H., Roberts, R. W., \& Patten, D. M. (2010). The language of US corporate environmental disclosure. Accounting, Organizations and Society, 35(4), 431443. 
Cho, H., \& Yoon, H. (2013). A corpus-assisted comparative genre analysis of corporate earnings calls between Korean and native-English speakers. English for Specific Purposes, 32(3), 170-185.

Choi, J. S., Lim, H. J., \& Mali, D. (2017). Mandatory audit firm rotation and Big4 effect on audit quality: Evidence from South Korea. Asian Academy of Management Journal of Accounting and Finance, 13(1), 1-40.

Craft, J. A. (1981). Information disclosure and the role of the accountant in collective bargaining. Accounting, Organizations and Society, 6(1), 97-107.

Cuozzo, B., Dumay, J., Palmaccio, M., \& Lombardi, R. (2017) . Intellectual capital disclosure: a structured literature review. Journal of Intellectual Capital, 18(1), 9-28.

Curado, C., Henriques, L., \& Bontis, N. (2011). Intellectual capital disclosure payback. Management Decision. 49(7), 1080-1098.

De Silva, T.-A., Stratford, M., \& Clark, M. (2014). Intellectual capital reporting: A longitudinal study of New Zealand companies. Journal of Intellectual Capital, 15(1), 157-172.

De Villiers, C., \& Sharma, U. (2020). A critical reflection on the future of financial, intellectual capital, sustainability and integrated reporting. Critical Perspectives on Accounting, 70 (In press).

Deegan, C. (2009), Financial Accounting Theory, 3rd ed., McGraw Hill, Sydney.

Deloitte, (2015). Non-financial reporting. Available from: https://www2.deloitte.com/content/dam/Deloitte/lv/Documents/strategy/ Non-financial reporting 2015.pdf

Duff, A. (2018). Intellectual capital disclosure: evidence from UK accounting firms. Journal of Intellectual Capital, 8(2), 236-255. 
Dumay, J. (2016). A critical reflection on the future of intellectual capital: from reporting to disclosure. Journal of Intellectual Capital, 17(1), 168-184.

Dumay, J., \& Garanina, T. (2013). Intellectual capital research: A critical examination of the third stage. Journal of Intellectual Capital, 14(1), 10-25.

El-Haj, M., Alves, P., Rayson, P., Walker, M., \& Young, S. (2020). Retrieving, classifying and analysing narrative commentary in unstructured (glossy) annual reports published as $\quad$ PDF files. Accounting and Business Research, 50(1), 6-34.

Eccles, R., Herz, R., Keegan, E. \& Phillips, D. (2001). The Value Reporting Revolution: Moving Beyond the Earnings Game. John Wiley \& Sons, New York, NY.

Eckstein, C. (2004). The measurement and recognition of intangible assets: then and now. Accounting Forum, 28(2), 139-158.

Edvinsson, L., \& Sullivan, P. (1996). Developing a model for managing intellectual capital. European Management Journal, 14(4), 356-364.

Ferraris, A., Del Giudice, M., Grandhi, B., \& Cillo, V. (2019). Refining the relation between cause-related marketing and consumers purchase intentions: a cross-country analysis. International Marketing Review, 37(4), 651-669.

Fincham, R., \& Roslender, R. (2003). Intellectual capital accounting as management fashion: A review and critique. European Accounting Review, 12(4), 781795.

Flamholtz, E. G. (1974). Human resource accounting. California: Dickenson Publishing Company.

Flamholtz, E. G. (1974). The Metaphysics of Human Resource Accounting and Its Implications for Managerial Accounting. Accounting Forum, 1974(12), 51-61. 
Flower, J. (2015). The international integrated reporting council: A story of failure. Critical Perspectives on Accounting, 27(1), 1-17.

García-Sánchez, I. M., \& Noguera-Gámez, L. (2017). Integrated reporting and stakeholder engagement: The effect on information asymmetry. Corporate Social Responsibility and Environmental Management, 24(5), 395-413.

Global Reporting Initiative (GRI) (2013). G4 sustainability reporting guidelines: Reporting principles and standard disclosures. Amsterdam: Global Reporting Initiative.

Goh, P.C. and Lim, K.P. (2004), Disclosing intellectual capital in company annual reports: evidence from Malaysia, Journal of Intellectual Capital, 5(3), 500510.

Gowthorpe, C. (2009). Wider still and wider? A critical discussion of intellectual capital recognition, measurement and control in a boundary theoretical context. Critical Perspectives on Accounting, 20(7), 823-834.

Gray, R., Kouhy, R., \& Lavers, S. (1995). Methodological themes: constructing a research database of social and environmental reporting by UK companies. Accounting, Auditing \& Accountability Journal, 8(2), 78.

Guthrie, J., \& Petty, R. (2000). Intellectual capital: Australian annual reporting practices. Journal of Intellectual Capital, 1(3), 241-251.

Guthrie, J., Petty, R. and Ricceri, F. (2004), External intellectual capital reporting: contemporary evidence from Hong Kong and Australia, paper presented at the International IC Congress, Helsinki, 2-3 September.

Guthrie, J., Petty, R. and Ricceri, F. (2006). The voluntary reporting of intellectual capital. Journal of Intellectual Capital, 7(2), 254-271.

Guthrie, J., Ricceri, F., \& Dumay, J. (2012). Reflections and projections: a decade of 
intellectual capital accounting research. The British Accounting review, 44(2), 68-82.

Hekimian, J. S., \& Jones, C. (1967). Put people on your balance sheet. Harvard Business Review, $\quad 43(2), 105-113$.

Hermanson, R. H. (1964). Accounting for human assets (Occasional Paper No. 14). East Lansing. MI: Bureau of Business and Economic Research. Michigan State University.

Hitt, M. A., Carnes, C. M., \& Xu, K. (2016). A current view of resource-based theory in operations management: A response to Bromiley and Rau. Journal of Operations Management, 41(10), 107-109.

Hofstede, G. (2001). Culture's consequences: Comparing values, behaviors, institutions and organizations across nations. Sage publications.

Hopwood, A. G. (2009). Accounting and the environment. Accounting, Organizations and Society, 34, 433-439.

Huang, C. C., Luther, R., Tayles, M., \& Haniffa, R. (2013). Human capital disclosures in developing countries: figureheads and value creators. Journal of Applied Accounting Research, 14(2), 180-196.

Husillos, J., González, C. L., \& Gil, M. J. Á. (2011). The emergence of triple bottom line reporting in Spain. Spanish Journal of Finance and Accounting/Revista Española de Financiación y Contabilidad, 40(150), 195-219.

Husin, N. M., Hooper, K., \& Olesen, K. (2012). Analysis of intellectual capital disclosure-an illustrative example. Journal of Intellectual Capital, 13(2), 196220.

IFRS, C. (2018). Conceptual framework for financial reporting. IFRS Foundation. International Integrated Reporting Council (IIRC) 2013, “The international IR 
framework", available at:

https://integratedreporting.org/wp-content/uploads/2013/12/13-12-08-

THE-INTERNATIONAL-IR-FRAMEWORK-2-1.pdf (accessed 1 January 2019).

International Integrated Reporting Council (IIRC) 2015a, available at:

https://integratedreporting.org/wp-content/uploads/2015/03/13-12-08-THE-

INTERNATIONAL-IR-FRAMEWORK-2-1.pdf

International Integrated Reporting Council (IIRC) 2015b, , available at:

https://integratedreporting.org/wp-content/uploads/2015/08/IR-Banking-

Network-Publication.pdf

Jackson, G., Bartosch, J., Avetisyan, E., Kinderman, D., \& Knudsen, J. S. (2020). Mandatory non-financial disclosure and its influence on CSR: An international comparison. Journal of Business Ethics, 162(2), 323-342.

Johanson, U., Mårtensson, M., \& Skoog, M. (2001). Mobilizing change through the management control of intangibles. Accounting, Organizations and Society, 26(7-8), 715-733.

Jung, Y. (2012). Work orientation in Korean CEO's on-line greetings. Online Journal of Communication and Media Technologies, 2(2), 153-181.

Khan, M. H. U. Z., \& Khan, M. R. (2010). HC disclosure practices of top Bangladeshi companies. Journal of Human Resource Costing \& Accounting, 14(4), 329349.

Khan, T., \& Gray, R. (2016). Accounting, identity, autopoiesis sustainability: A comment, development and expansion on Lawrence, Botes, Collins and Roper (2013). Meditari Accountancy Research, 24(1), 36-55.

Kim, S., Lim, H., \& Park, D. (2010). Productivity and employment in a developing country: Some evidence from Korea. World Development, 38(4), 514-522. 
Kim, J. W., \& Rowley, C. (2006). Commitment to company and labour union: Empirical evidence from South Korea. The International Journal of Human Resource Management, 17(4), 673-692.

Kirkman, P., \& Hope, C. (1992). Environmental disclosure in UK company annual reports (p. 21). University of Cambridge, Management Studies Group.

Koumenta, M., \& Williams, M. (2019). An anatomy of zero-hour contracts in the UK. Industrial Relations Journal, 50(1), 20-40.

KPMG (2016). Carrot \& Sticks. Sustainability Reporting Policies Worldwide -Today's Best Practice, Tomorrow's Trends.

Knauer, A., \& Serafeim, G. (2014). Attracting long-term investors through integrated thinking and reporting: a clinical study of a biopharmaceutical company. Journal of Applied C Corporate Finance, 26(2), 57-64.

La Porta, R., Lopez-de-Silanes, F., Shleifer, A., \& Vishny, R. W. (1997). Legal determinants of external finance. The Journal of Finance, 52(3), 1131-1150.

Lee, J. W. (2005). Human capital and productivity for Korea's sustained economic growth. Journal of Asian Economics, 16(4), 663-687.

Lee, Y. (2015). Labor after neoliberalism: The birth of the insecure class in South Korea. Globalizations, 12(2), 184-202.

Lee, K. W., \& Yeo, G. H. H. (2016). The association between integrated reporting and firm valuation. Review of Quantitative Finance and Accounting, 47(4), 12211250.

Leung, T. C. H., \& Gray, R. (2016). Social responsibility disclosure in the international gambling industry: A research note. Meditari Accountancy Research, 24 (1), 73-90.

Lev, B., \& Zambon, S. (2003). Intangibles and intellectual capital: an introduction to a 
special issue. European Accounting Review, 12(4), 597-603.

Li, J., Pike, R., \& Haniffa, R. (2008). Intellectual capital disclosure and corporate governance structure in UK firms. Accounting and Business Research, 38(2), 137-159.

La Ferle, C., Kuber, G., \& Edwards, S. M. (2013). Factors impacting responses to causerelated marketing in India and the United States: Novelty, altruistic motives, and company origin. Journal of Business Research, 66(3), 364-373.

Lim, H. J., \& Mali, D. (2020). Does the productivity of labor influence credit risk? new evidence from South Korea. Asia-Pacific Journal of Accounting \& Economics, 27(3), 280-299.

Lim, H. J., \& Mali, D. (2020). Do credit ratings influence the demand/supply of audit effort?. Journal of Applied Accounting Research. 22(1), 72-92

Lindblom, C.K. (1993). The implications of organisational legitimacy for corporate social performance and disclosure, paper presented at the Critical Perspectives on Accounting Conference, New York, NY.

Mali, D., \& Lim, H. J. (2018). Conservative reporting and the incremental effect of mandatory audit firm rotation policy: a comparative analysis of audit partner rotation vs audit firm rotation in South Korea. Australian Accounting Review, 28(3), 446-463.

Mali, D., \& Lim, J. H. (2019). The influence of firm efficiency on agency credit ratings. Journal of Credit Risk, 15(1). 1-26

Mali, D., \& Lim, H. J. (2020, November). Can audit effort (hours) reduce a firm's cost of capital? Evidence from South Korea. In Accounting Forum, (1-29).

Mali, D., \& Lim, H. J. (2021). Do Relatively More Efficient Firms Demand Additional Audit Effort (Hours)?. Australian Accounting Review, 31(2), 108-127. 
Marr, B., \& Chatzkel, J. (2004). Intellectual capital at the crossroads: Managing, measuring, and reporting of IC. Journal of Intellectual Capital, 5(2), 224-229.

Martin, L. M., Warren-Smith, I., Scott, J. M., \& Roper, S. (2008). Boards of directors and gender diversity in UK companies. Gender in Management: An International Journal, 23(3), 194-208.

Maunders, K. T., \& Foley, B. J. (1984). Information disclosure and the role of the accountant in collective bargaining-some comments. Accounting, Organizations and Society, 9(1), 99-106.

Mautz Jr, R. D. (1990). Inflation-adjusted disclosures and the determination of ability to pay in collective bargaining. Accounting, Organizations and Society, 15(4), 273-295

McCracken, M., McIvor, R., Treacy, R., \& Wall, T. (2018). A study of human capital reporting in the United Kingdom. In Accounting Forum 42(1), 130-141.

McPhail, K. (2009). Where is the ethical knowledge in the knowledge economy? Power and potential in the emergence of ethical knowledge as a component of intellectual capital. Critical Perspectives on Accounting, 20(7), 804-822.

Melloni, G. (2015). Intellectual capital disclosure in integrated reporting: an impression management analysis. Journal of Intellectual Capital, 16(3), 661680.

Meritum. (2002). Measuring Intangibles to Understand and Improve Innovation Management. European Commission, Brussels.

Merkl-Davies, D. M., \& Brennan, N. M. (2007). Discretionary disclosure strategies incorporate narrtives: Incremental information or impression management? Journal of Accounting ～Literature, 26(i), 116-196.

Metcalf, D. (1989). Water notes dry up: the impact of the Donovan reform proposals 
and Thatcherism at work on labour productivity in British manufacturing industry. British Journal of Industrial Relations, 27(1), 1-31.

Michelon, G., Pilonato, S., \& Ricceri, F. (2015). CSR reporting practices and the quality of disclosure: An empirical analysis. Critical Perspectives on Accounting, 33(2015), 59-78.

Mistry, V., Sharma, U., \& Low, M. (2014). Management accountants' perception of their role in accounting for sustainable development: An exploratory study. Pacific Accounting Review, 26(1/2), 112-133.

Mitchell, J. D., Chia, C. W., \& Loh, A. S. (1995). Voluntary disclosure of segment information: Further Australian evidence. Accounting \& Finance, 35(2), 1-16.

Moneva, J., Archel, P., \& Correa, C. (2006). GRI and the camouflaging of corporate unsustainability. Accounting Forum, 30(2006), 121-137.

Mouritsen, J., Larsen, H. T., \& Bukh, P. N. (2001). Intellectual capital and the 'capable firm': narrating, visualising and numbering for managing knowledge. Accounting, $\quad$ Organizations and Society, 26(7-8), 735-762.

Mouritsen, J., \& Roslender, R. (2009). Critical intellectual capital. Critical Perspectives on Accounting, 20(7), 801-803.

Newson, M., \& Deegan, C. (2002). Global expectations and their association with corporate social disclosure practices in Australia, Singapore, and South Korea. The International Journal of Accounting, 37(2), 183-213.

Nolan, P. (1989). Walking on water? Performance and industrial relations under Thatcher. Industrial Relations Journal, 20(2), 81-92.

Nolan, P. (2011). Money, markets, meltdown: the 21st-century crisis of labour. Industrial Relations Journal, 42(1), 2-17.

Nolan, P. (2012). Understanding the employment relationship: markets, hierarchies 
and power. Industrial Relations Journal, 43(4), 359-369.

Power, M. (2001). Imagining, measuring and managing intangibles. Accounting, Organizations $\quad$ and Society, 7(26), 691-693.

Rao, K., \& Tilt, C. (2016). Board diversity and CSR reporting: An Australian study. Meditari $\quad$ Accountancy Research, 24(2), 182-210.

Roslender, R., \& Stevenson, J. (2009). Accounting for people: a real step forward or more a case of wishing and hoping? Critical Perspectives on Accounting, 20(7), 855-869.

Roslender, R., Stevenson, J. E., \& Kahn, H. (2012). Towards recognising workforce health as a constituent of intellectual capital: Insights from a survey of UK accounting and finance directors. Accounting Forum, 36(4), 266-278.

Sánchez, P., Asplund, R., Stolowy, H., Roberts, H., Johanson, U., \& Mouritsen, J. (2001). Measuring intangibles to understand and improve innovation management Target Socio-Economic Research, Brussels: European Commission.

Serafeim, G. (2015). Integrated reporting and investor clientele. Journal of Applied Corporate Finance, 27(2), 34-51.

Siegel, P. H. (2006). The measurement and recognition of intangible assets. Journal of Public Affairs, 1(1), 1-12.

Singh, S., \& Kansal, M. (2011). Voluntary disclosures of intellectual capital. Journal of Intellectual Capital, 12(2), 301-318.

Steen, A., Welch, D., \& McCormack, D. (2011). Conflicting conceptualizations of human resource accounting. Journal of Human Resource Costing \& Accounting, 15(4), $299-312$.

Stolowy, H., \& Paugam, L. (2018). The expansion of non-financial reporting: an exploratory study. Accounting and Business Research, 48(5), 525-548. 
Striukova, L., Unerman, J., \& Guthrie, J. (2008). Corporate reporting of intellectual capital: Evidence from UK companies. The British Accounting Review, 40(4), 297-313.

Subbarao, A. V., \& Zéghal, D. (1997). Human resources information disclosure in annual reports: an international comparison. Journal of Human Resource Costing \& Accounting, 2(2), 53-73.

Suchman, M.C. (1995), "Managing legitimacy: strategic and institutional approaches", Academy of Management Review, 20(3), 571-610.

Sun, X., Li, H., \& Ghosal, V. (2020). Firm-level human capital and innovation: evidence from China. China Economic Review, 59, (in press)

Sung, S. Y., \& Choi, J. N. (2018). To invest or not to invest: strategic decision making toward investing in training and development in Korean manufacturing firms. The International Journal of Human Resource Management, 29(13), 2080-2105.

Sveiby, K. E. (1997). Intangible assets monitor. Journal of Human Resources Costing and Accounting, 2(1), 73-79.

Tinker, A. M. (1980). Towards a political economy of accounting: an empirical illustration of the Cambridge controversies. Accounting, Organizations and Society, 5(1), 147-160.

Tinker, T., \& Neimark, M. (1987). The role of annual reports in gender and class contradictions at General Motors: 1917-1976. Accounting, Organizations and Society, 12(1),71-88.

Tsai, W., \& Ghoshal, S. (1998). Social capital and value creation: The role of intra-firm networks. Academy of Management Journal, 41(4), 464-476.

Upton, W. (2001). Special report on business and financial reporting, challenges from 
the new economy. Financial Accounting Standards Board, Norwalk, CT.

Vandemaele, S. N., Vergauwen, P. G. M. C., \& Smits, A. J. (2005). Intellectual capital disclosure in The Netherlands, Sweden and the UK. Journal of intellectual Capital, 6(3), 417-426.

Veltri, S., \& Silvestri, A. (2015). The Free State University integrated reporting: a critical consideration. Journal of Intellectual Capital, 16(2), 443-462.

Vergauwen, P. G., \& Van Alem, F. J. (2005). Annual report IC disclosures in the Netherlands, France and Germany. Journal of Intellectual Capital, 6(1), 89-104. Vitolla, F., Raimo, N., \& Rubino, M. (2019). Intellectual capital disclosure and firm performance: $\quad$ An empirical analysis through integrated reporting. In 7 th International OFEL Conference on Governance, Management and Entrepreneurship: Embracing Diversity in Organisations. April 5th-6th, 2019, Dubrovnik, Croatia (pp. 245-255). Zagreb: Governance Research and Development Centre (CIRU).

Wall, A. P., Kirk, R. J., \& Martin, G. (2003). Intellectual capital: Measuring the immeasurable. Oxford: Elsevier.

World Trade organization / WTO. (2021). Groups in negotiations: Accessed on the $20 / 4 / 2021$

https://www.wto.org/english/tratop e/dda e/negotiating groups e.htm\#grp002b

Wilburn, K., \& Wilburn, R. (2013). Using global reporting initiative indicators for CSR programs. Journal of Global Responsibility, 4(1), 62-75.

Woods, C. (2013). Classifying South Korea as a developed market. White Paper Report. Zhou, S., Simnett, R., \& Green, W. (2017). Does integrated reporting matter to the capital market? Abacus, 53(1), 94-132. 
' employee, career, human, training, ethics, health, safety, satisfaction, people, talent, well, staff entrepreneur, diversity, education, engagement, labour, labor, grievance, disciplinary, loyalty, occupational, recruitment, retainment, apprentice, colleague, male, female 